\title{
Immunoreactive pancreatic Reg protein in sera from cystic fibrosis patients with and without pancreatic insufficiency
}

\author{
J Carrère, O Guy-Crotte, E Gaia, C Figarella
}

\begin{abstract}
Background-The biological function of the Reg protein, a non-enzymic protein produced in fairly large amounts by pancreatic acinar cells, remains elusive. Its susceptibility to proteolysis leading to precipitation of the proteolysis product at neutral $\mathrm{pH}$ suggests that it could contribute to the protein plugging observed in cystic fibrosis (CF).

Aims-To study its behaviour in the serum of CF patients with or without pancreatic insufficiency and to compare it with that of other pancreatic secretory proteins.

Patients-170 patients (93 with CF, 55 controls, and 22 with chronic pancreatitis) were studied.

Methods-Reg protein was measured using a specific enzyme immunoassay and its molecular form in CF sera was characterised by gel filtration. Molecular gene expression was investigated by dot-blot hybridisation.
\end{abstract}

Results-Reg protein was present in all CF sera studied from patients with or without pancreatic insufficiency, and in all cases the level was significantly higher than in controls. Its chromatographic behaviour in CF sera was identical with that of the protein present in normal serum. No correlation was found between the levels of Reg protein and trypsin(ogen) (or lipase) in CF, nor in control sera or normal pancreatic juice. Molecular gene expression of the corresponding proteins investigated in pancreatic tissues showed an absence of correlation between the mRNA levels.

Conclusions-Reg protein may not be a secretory exocrine protein like the digestive enzymes but rather a hormone-like secretory substance with an endocrine or paracrine function.

(Gut 1999;44:545-551)

Keywords: Reg protein; serum; cystic fibrosis; pancreatic insufficiency

Patients with cystic fibrosis (CF) can be categorised according to the functional status of the exocrine pancreas. ${ }^{1}$ The vast majority of CF patients (about 85-90\%) have pancreatic insufficiency (PI) requiring exogenous pancreatic replacement therapy with meals. The remaining patients also have evidence of pancreatic disease but have sufficient pancreatic enzyme output to maintain normal nutri- ent digestion and assimilation without the need for pancreatic enzyme supplementation. The latter group is therefore considered to be pancreatic sufficient (PS). Longitudinal data provided on 78 patients with $\mathrm{CF}$ identified in a newborn cystic fibrosis programme have shown that, at diagnosis, $38 \%$ of patients were PS but over a period of three to 36 months a considerable number of these patients became $\mathrm{PI}^{2}$ These findings suggest that the progression of pancreatic disease in patients with CF and PS should be monitored, but most clinical methods used for assessing exocrine pancreatic function are either too invasive or too insensitive to be considered useful. A non-invasive test such as the measurement of blood immunoreactive trypsin level appears to have significant age related limitations in CF patients, because of the significant increase in the serum pancreatic enzyme at birth in infants with PI. ${ }^{3}$

In the 1980s an unusual secretory protein was identified in human pancreas. ${ }^{45}$ The first evidence was its susceptibility to proteolysis and the fact that the proteolytic product precipitated at neutral $\mathrm{pH}$ forming fibrils, prompting the name pancreatic thread protein. ${ }^{5}$ This $14 \mathrm{kDa}$ proteolytic product was the first to be identified in the pancreatic juice under the name of protein $\mathrm{X}^{4}$ and in pancreatic precipitates and stones where it was given the name pancreatic stone protein. ${ }^{67}$ Later, the soluble precursor was fully characterised as a $19 \mathrm{kDa}$ non-enzymic secretory glycoprotein, and it was found that removal of the N-terminal glycosylated undecapeptide by trypsin cleavage generates the polypeptide that is insoluble at neutral $\mathrm{pH}$. This secretory protein was later found to be $100 \%$ identical with a protein encoded by a gene related to regeneration of pancreatic $\beta$-cell and named "Reg" for regenerating. ${ }^{89}$

In a previous study, Forstner et $a l^{10}$ studying pancreatobiliary secretions of CF patients showed selective precipitation of Reg in the concentrated samples of duodenal secretions provided from these patients as well as from control patients, suggesting that this protein may contribute to the protein plugging observed in CF. It was therefore of interest to investigate Reg protein concentration in the serum of CF patients to see if its measurement could be useful in the monitoring of pancreatic

Abbreviations used in this paper: $\mathrm{CF}$, cystic fibrosis; PS, pancreatic sufficiency; PI, pancreatic insufficiency; CP, chronic pancreatitis; PAP/HIP, pancreatitis associated protein/hepatocarcinomaintestine-pancreas. 
status in CF patients. The results presented here show that Reg is present in all CF serum, from both patients with PS and PI, at a higher concentration than in normal serum. In addition, our data led to the interesting hypothesis that Reg is not a secretory exocrine protein like the digestive enzymes but is rather a hormone-like secretory substance with an endocrine or paracrine function.

\section{Materials and methods}

MATERIALS

Human pancreatic juices $(n=7)$ devoid of free proteolytic activity were obtained by catheterisation of the Wirsung duct of patients without pancreatic disease and after surgery for biliary disease as previously described. ${ }^{11}$ The samples were stored as a lyophilised powder at $-20^{\circ} \mathrm{C}$. Lyophilised pancreatic juices were first dissolved in $1 \mathrm{mM}$ benzamidine to avoid zymogen activation and the protein concentration was estimated using an absorption coefficient of 20.0. The samples of pancreatic juice were then diluted in bovine serum at a protein concentration of around $22 \mu \mathrm{g} / \mathrm{ml}$ before assay. The same solutions were used for Reg protein, trypsin (ogen), and lipase immunoassays.

Adult pancreatic tissues $(\mathrm{n}=7)$ were obtained from transplant donors and/or from patients having surgery; the tissues were immediately frozen.

Samples of recombinant pancreatitis associated protein/hepatocarcinoma-intestine-pancreas (PAP/HIP; expressed in Escherichia coli $)^{12}$ and specific antibody to PAP/HIP were gifts from Laurence Christa (INSERM U370, Paris, France). Trypsinogen and lipase cDNA probes were synthesised by reverse transcription and polymerase chain reaction (PCR) as described by Moriscot et al. ${ }^{13}$ Reg cDNA probe, kindly given by Dr H Okamoto (Tohoku University School of Medicine, Japan) was a $600 \mathrm{bp}$ fragment cloned into pBluescript vector. 28S cDNA probe was from American Type Culture Collection (Rockville, Maryland, USA).

PREPARATION OF SERUM SAMPLES

Blood samples collected in standard tubes were allowed to clot at room temperature, centrifuged for $10 \mathrm{~min}$ at $1700 \mathrm{~g}$, and the sera stored at $-80^{\circ} \mathrm{C}$ until assay. A total of 148 serum samples obtained from 55 controls and $93 \mathrm{CF}$ patients were studied. In addition, sera from 22 patients with chronic pancreatitis (CP) were compared; CP was confirmed on clinical grounds, the presence of pancreatic calcification, and findings of the cholecystokinin secretion test, endoscopic retrograde cholangiopancreatography, or pancreatic histology.

The 55 control sera consisted of 38 collected from apparently healthy adult volunteers under fasting conditions, and 17 from newborns and babies (aged from 15 days to 20 months) which had been sent to our laboratory for trypsin (ogen) immunoassay because of a suspicion of CF but shown to be normal.

Of the 93 serum samples from patients with CF, 76 (provided by the paediatric service of Hôpital Renée Sabran, Giens, France) were
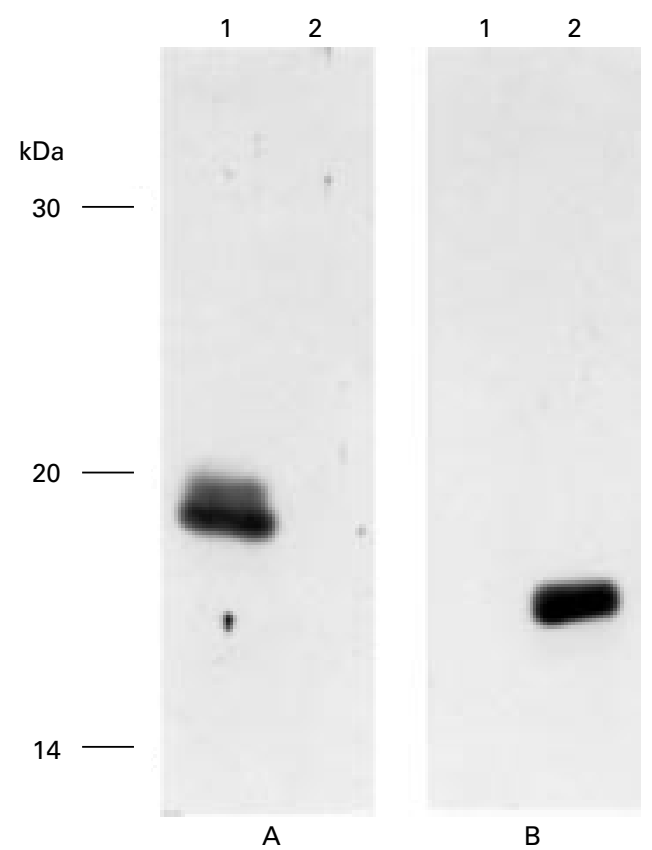

Figure 1 Immunoblotting of anti-Reg protein and anti-PAP/HIP. Partially purified Reg protein $(0.4 \mu \mathrm{g}$; lane 1) and purified HIP (0.4 $\mu$ g; lane 2) were electrophoresed on SDS/12.5\% polyacrylamide gel and then transferred to nitrocellulose. Immunodetection was performed with anti-Reg (1:500 dilution) $(A)$ and anti-PAP/HIP (1:500 dilution) (B) and detected by enhanced chemiluminescence (Amersham kit) after incubation with horseradish peroxidase labelled anti-rabbit IgG (1:5000 dilution). The positions of the molecular mass markers are indicated.

from patients aged 5-29 years (mean (SD) age 17.5 (6.1) years). Eleven were from PS patients and 65 from PI patients. PS patients were defined by having a fat absorption coefficient of over $90 \%$ in the absence of opotherapy and not requiring oral pancreatic supplements. PI patients had a fat absorption coefficient lower than $90 \%$ without treatment and required oral pancreatic replacement therapy with meals.

The remaining 17 serum samples (provided by Yves Barbier, Hôpital Debrousse, Lyon, France) were from newborns and babies (aged from 15 days to 21 months) being screened for cystic fibrosis. These sera displayed a high level of immunoreactive trypsin(ogen) as measured by radioimmunoassay (RIA-gnost; Behring, Marburg, Germany), with 10 of the 17 samples having the highest level of measurable immunoreactive trypsin(ogen) $(>1180 \mathrm{ng} / \mathrm{ml})$. These newborns and babies were further shown by genotyping to have CF.

IMMUNOENZYMIC ASSAY OF THE REG PROTEIN Reg protein concentration was measured by a direct sandwich immunoassay ${ }^{14}$ on $0.1 \mathrm{ml}$ serum, pancreatic juice, or chromatography fractions diluted to a final volume of $0.3 \mathrm{ml}$ in the diluting medium $(0.2 \mathrm{M}$ phosphate buffer, $\mathrm{pH} 7.2,10 \%$ rabbit serum). As a solid phase, $6.5 \mathrm{~mm}$ diameter polystyrene balls were coated with specific IgG, and horseradish peroxidase labeled IgG was used as a secondary antibody. Peroxidase activity was measured using $o$-phenylenediamine dihydroxychloride as substrate. 

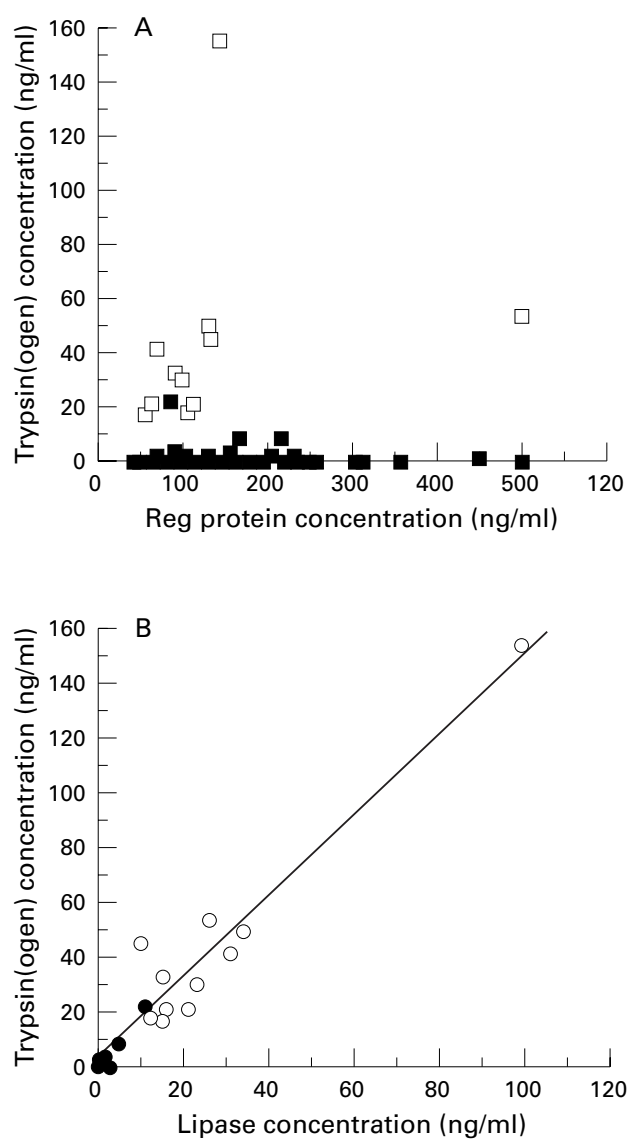

Figure 2 Comparison of Reg protein, trypsin(ogen), and lipase levels in sera of cystic fibrosis patients with pancreatic sufficiency (open symbols) and pancreatic insufficiency (solid symbols). (A) Absence of correlation between Reg protein and trypsin (ogen) concentration; (B) correlation between lipase and trypsin(ogen) concentrations.

To be sure of the specificity of the antibody to Reg, we checked the absence of cross reactivity with PAP/HIP, a closely related protein shown to be increased in neonates with $\mathrm{CF}^{15}$ A sample of recombinant PAP/HIP and a sample of human pancreatic juice were submitted to immunoblotting using antibodies to Reg. As expected, a band of $19 \mathrm{kDa}$ corresponding to the glycosylated form of the protein present in pancreatic juice was detected with our antibodies whereas no immunoreactivity was observed with PAP/HIP (fig 1), indicating that the antibody used was specific to Reg. In contrast, pure HIP was recognised by the antibody to recombinant PAP/HIP. On the other hand, we verified that PAP/HIP, tested at a concentration of $1 \mu \mathrm{g} / \mathrm{ml}$, was not recognised by the immunoenzymic assay for Reg.

DETERMINATION OF TRYPSIN(OGEN), CHYMOTRYPSIN(OGEN), AND LIPASE

CONCENTRATIONS

Blood trypsin(ogen) levels were determined by an immunoenzymic assay as previously described. ${ }^{16}$ The assay was shown to specifically recognise the major human trypsinogen: trypsinogen 1 or "cationic" trypsinogen. Blood lipase and chymotrypsin(ogen) levels were determined by immunoenzymic assay as described previously. ${ }^{17} 18$
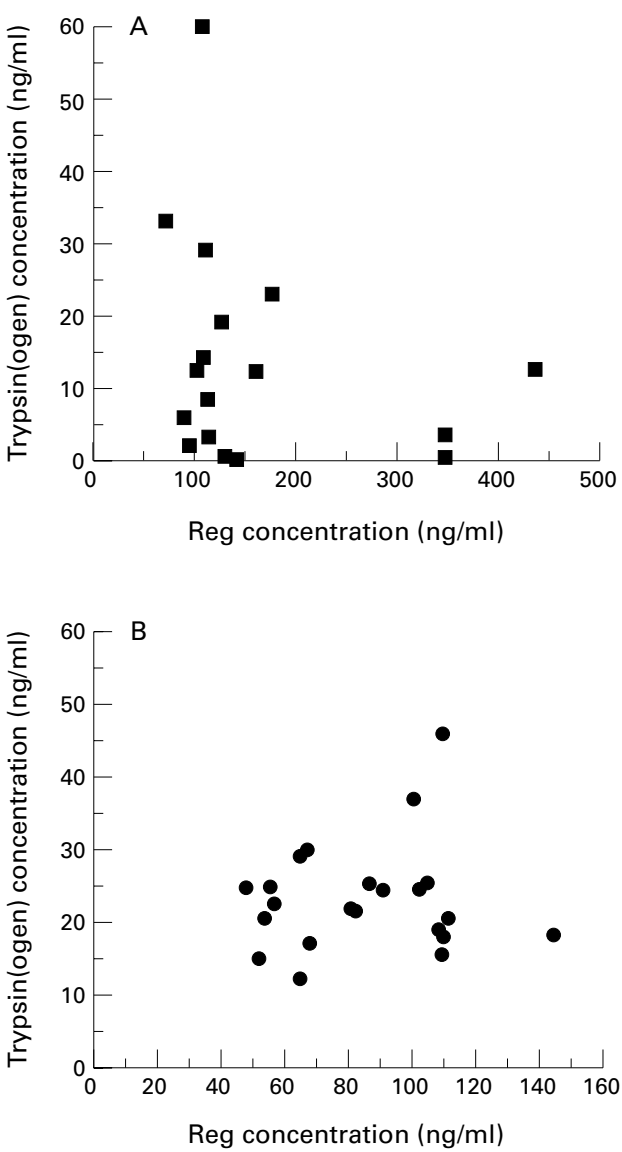

Figure 3 Absence of correlation between Reg protein and trypsin(ogen) levels in the serum of patients with chronic pancreatitis $(A)$ and controls $(B)$.

\section{GEL FILTRATION}

Serum filtration was performed on a column $(1.5 \mathrm{~cm} \times 90 \mathrm{~cm})$ of Sephadex G-100-SF (Pharmacia Fine Chemicals, Uppsala, Sweden) in a $50 \mathrm{mM}$ Tris $/ \mathrm{HCl}$ buffer, $\mathrm{pH}$ 7.6, containing $200 \mathrm{mM} \mathrm{NaCl}$. Proteins were assayed by measuring absorbance at $280 \mathrm{~nm}$, and elution of trypsin(ogen) and Reg was controlled by immunoenzymic assay of each fraction. The column was calibrated with the following proteins: bovine serum albumin (67 $\mathrm{kDa})$, ovalbumin (45 kDa), bovine chymotrypsinogen $(25 \mathrm{kDa})$, and cytochrome $c$ (14 $\mathrm{kDa})$.

QUANTITATIVE ANALYSIS OF MRNA BY DOT-BLOT HYBRIDISATION

Adult pancreatic RNA was prepared as described by Chirgwin et $a l^{19}$ with slight modifications as previously explained. ${ }^{20}$ RNA integrity was confirmed by $1 \%$ formaldehyde/agarose gel electrophoresis, and qualitative analysis of mRNA was checked by Northern blot. ${ }^{13}$ Reg and trypsinogen mRNA were determined by dot-blot hybridisation in duplicate on each pancreas. Sequential dilutions of total RNA $(0.005-0.156 \mathrm{mg})$ were spotted on nitrocellulose membranes using a manifold apparatus (Minifold I; Schleicher \& Schuell, Dassel, Germany). Reg and trypsinogen mRNA levels were quantified after hybridisation with ${ }^{32} \mathrm{P}$-labeled Reg and trypsinogen cDNA probes respectively. For the hybridisation with the $28 \mathrm{~S}$ 

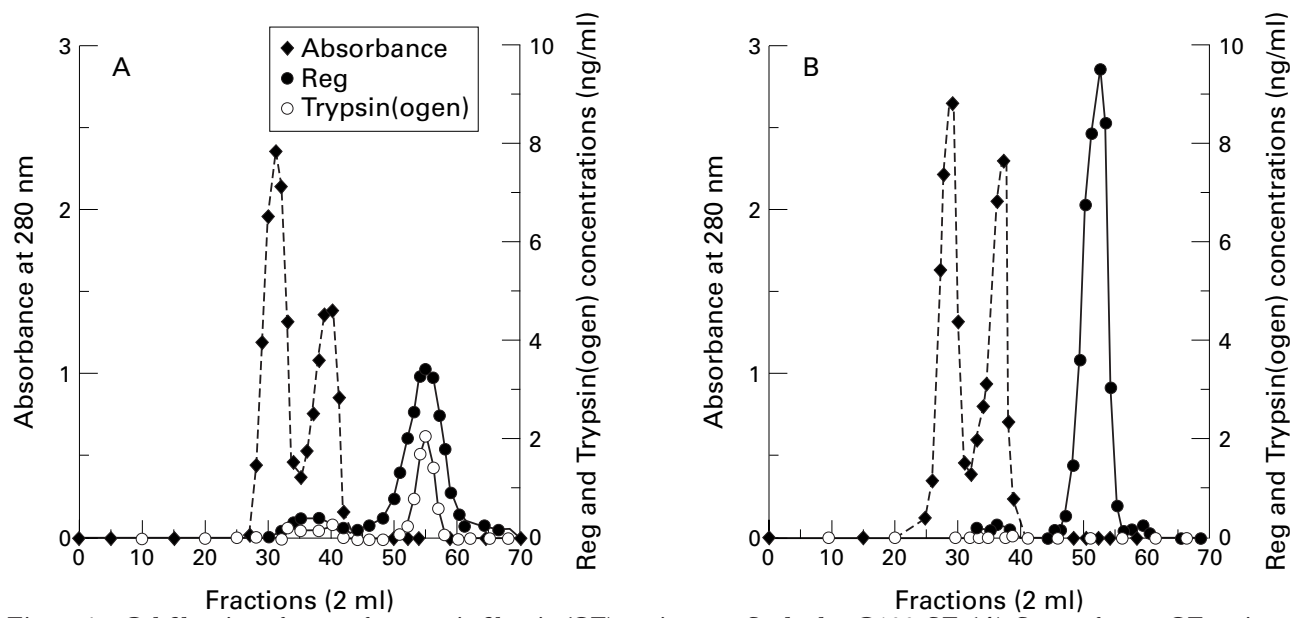

Figure 4 Gel filtration of serum from cystic fibrosis (CF) patients on Sephadex G100-SF. (A) Serum from a CF patient with pancreatic sufficiency; (B) serum from a $C F$ patient with pancreatic insufficiency. In each case, $0.5 \mathrm{ml}$ serum was loaded on a column $(1.5 \mathrm{~cm} \times 90 \mathrm{~cm})$ equilibrated in $200 \mathrm{mM} \mathrm{NaCl} / 50 \mathrm{mM}$ Tris/HCl buffer, pH 7.6. Fraction size, $2 \mathrm{ml}$.

cDNA probe, we used a 100-fold lower amount of total RNA and therefore the sequential dilutions were from 50 to $1.56 \mathrm{ng}$ of total pancreatic RNA. Filters were then exposed to $x$ ray films (Hyperfilm MR; Amersham International, Amersham, Bucks, UK). After autoradiography, the filter-bound radioactivity was determined by scanning autoradiograms at 490 $\mathrm{nm}$ using an optical densitometer (Dynatech MR 5000; Dynex, Issy-les-Moulineaux, France), and mRNA concentrations were estimated from the slopes of the linear regression curves of dot scans. The regression coefficient $r$ was always $\geqslant 0.98$. The densitometrically scanned readings for Reg and trypsinogen were corrected to the $28 \mathrm{~S}$ signal to eliminate possible differences in total RNA loading. Results were calculated as the ratio Reg/28S and trypsinogen/28S and expressed in arbitrary units (AU).

STATISTICAL ANALYSIS

Blood protein levels were expressed as means (SD) $(\mathrm{ng} / \mathrm{ml})$. Differences between groups were evaluated by Student's unpaired $t$ test.

\section{Results}

REG, TRYPSIN(OGEN), CHYMOTRYPSIN(OGEN), AND LIPASE LEVELS IN THE SERUM OF CF PATIENTS: COMPARISON WITH CONTROLS AND PATIENTS WITH CP

Newborns and babies with $C F$

Levels of Reg protein were found to be very high in the serum of $17 \mathrm{CF}$ newborns and babies up to 21 months $(864.3(539.0) \mathrm{ng} / \mathrm{ml})$ and a very large variation in the values was observed. Serum immunoreactive chymotrypsinogen with a mean level of 189.2 (107.2) $\mathrm{ng} / \mathrm{ml}$ was also very high and variable compared with that previously observed in normal newborns $(21.0(9.4) \mathrm{ng} / \mathrm{ml}){ }^{18}$ Similar high widely distributed levels were observed for lipase (37.8 (32.3) $\mathrm{ng} / \mathrm{ml}$ ) compared with previous results found in normal newborns (4.0 (2.7) $\mathrm{ng} / \mathrm{ml}){ }^{17}$

In the serum of 17 normal newborns and babies up to 20 months, the levels of Reg pro- tein (123 (60) ng/ml) were much lower and less scattered than in newborns and babies with CF.

\section{Adult patients with $C F$}

Two groups of CF patients were studied separately according to their pancreatic sufficiency. In all the $65 \mathrm{CF}$ patients with PI (53 of which had undetectable serum trypsin(ogen) and lipase), Reg protein was present in the serum at a concentration of $142(30) \mathrm{ng} / \mathrm{ml}$. There was no difference between diabetic and nondiabetic CF patients or between the different types of mutation (data not shown).

In the $11 \mathrm{CF}$ patients with PS, the mean Reg level in serum (136 (124) ng/ml) was similar to that found in CF patients with PI but with the same wide distribution as observed for newborns with CF. In these sera the same scatter was observed for trypsin(ogen) (47.9 (39.5) $\mathrm{ng} / \mathrm{ml})$ and lipase $(29.6(25.1) \mathrm{ng} / \mathrm{ml})$.

In all CF patients (PI and PS), no correlation was found between the level of Reg protein and trypsin(ogen) $(r=0.22)$ (fig $2 \mathrm{~A})$, whereas a very good correlation was observed between trypsin(ogen) and lipase ( $r=0.95)$ (fig 2B).

It was of interest to compare the concentrations of Reg protein in the sera of patients with $\mathrm{CP}$ with those found in the sera of CF patients (PI and PS). The mean serum level of Reg protein in CP patients was 160 (96) ng/ml, a value close to that observed in all adult CF patients (141 (93) $\mathrm{ng} / \mathrm{ml}$ ); both were significantly higher than in control sera (84.8 (29.9); $\mathrm{n}=$ 38 ) with $\mathrm{p} \leqslant 0.003$ and 0.002 respectively. When immunoreactive trypsin(ogen) was assayed, no correlation was found between Reg and trypsin(ogen) concentrations measured in $17 \mathrm{CP}$ sera (fig $3 \mathrm{~A}$ ), but it is interesting to note that a similar lack of correlation was also found in the sera of 22 controls $(r=0.11)$ (fig 3B).

MOLECULAR FORMS OF THE REG PROTEIN IN CF SERA

The fact that Reg was present in fairly large amounts in the serum of PI patients in which trypsin(ogen) and lipase were undetectable led us to look for a difference in the molecular 

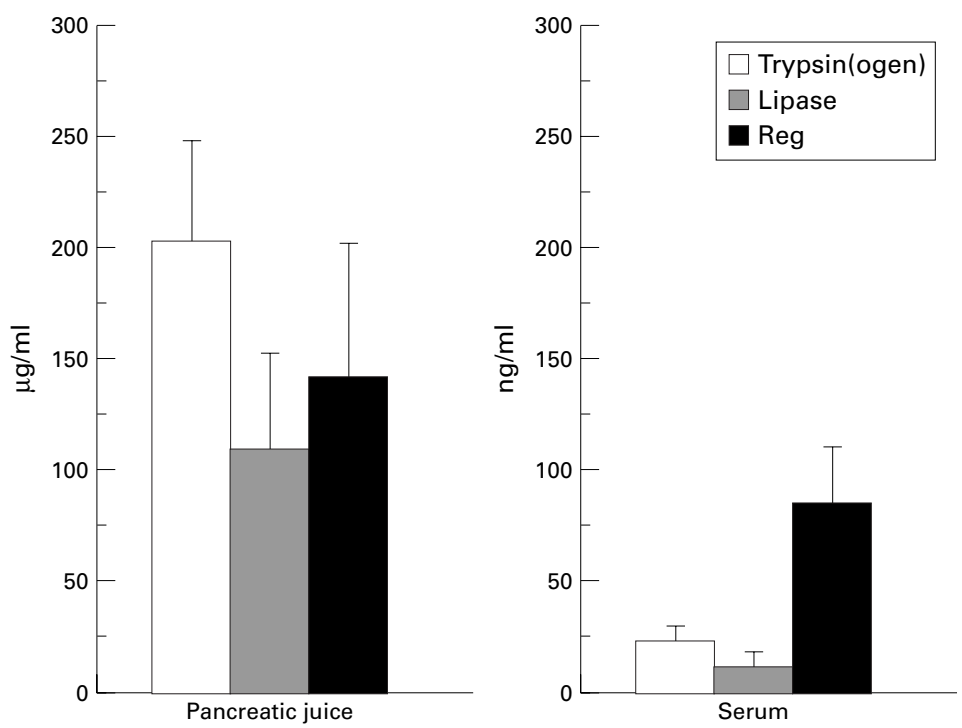

Figure 5 Trypsin(ogen), lipase, and Reg protein concentrations in pancreatic juice and serum. It is assumed that $1 \mathrm{ml}$ pancreatic juice contains $1 \mathrm{mg}$ protein.

form(s) of Reg protein in the serum of these patients. Sera obtained from PI and PS patients were submitted to gel filtration, and the molecular size distribution of Reg protein was determined by immunoassay of the protein in the different fractions (fig 4). Reg in serum from PS patients was eluted in one peak, with the fractions corresponding to proteins of 25 $\mathrm{kDa}$ and containing immunoreactive trypsinogen (fig 4A). This profile was similar to that observed on gel filtration of control serum (data not shown). For serum from PI patients, the Reg protein elution profile was the same, whereas, as expected, no immunoreactive trypsin(ogen) was detectable in any chromatographic fractions (fig 4B).

ABSENCE OF CORRELATION BETWEEN REG AND TRYPSIN(OGEN) OR LIPASE CONCENTRATIONS IN PANCREATIC JUICE AND BETWEEN REG AND TRYPSIN(OGEN) GENE EXPRESSIONS IN HUMAN PANCREATIC TISSUE

We investigated the possibility that the absence of correlation between Reg protein level on the one hand and trypsin(ogen) or lipase levels on the other in CF patients as well as in patients with CP and normal sera could be due to extrapancreatic events. We therefore quantified using the same assays the three proteins in seven samples of normal pancreatic juice and compared their relative concentrations in pancreatic juice and normal serum. As shown in fig 5 , the relative concentrations of trypsinogen and lipase in serum and pancreatic juice are comparable, but the concentration of Reg in relation to the other two is much higher in serum than in pancreatic juice. In addition, as observed for serum, no correlation was found between Reg and trypsin(ogen) (or lipase) concentrations in pancreatic juice whereas a good correlation was observed between trypsin(ogen) and lipase (data not shown).

At the molecular level, there was again a lack of correlation between the levels of Reg and trypsinogen mRNAs in pancreatic tissues (fig $6)$, contrasting with the positive correlation

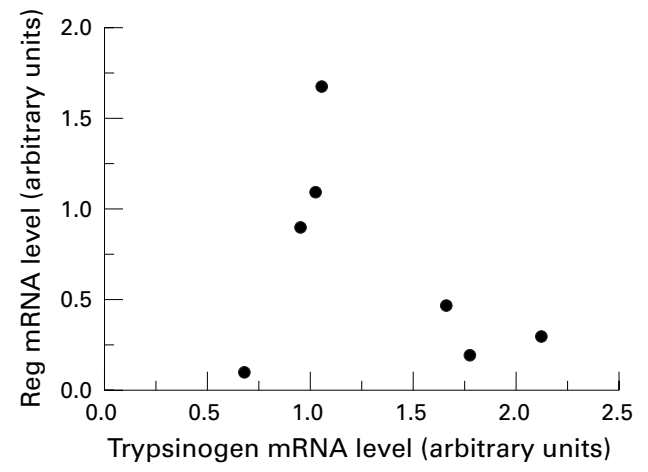

Figure 6 Absence of correlation between reg and trypsin (ogen) gene expression in human pancreas. $m R N A$ levels are expressed in arbitrary units $(A U)$ as the values of the densitometric scans of autoradiographs from dot-blot experiments after normalisation to the $28 S$ signals.

previously observed between trypsinogen and lipase mRNAs. ${ }^{13}$

\section{Discussion}

Human pancreatic secretion contains about 20 major protein components, more than $85 \%$ of which are directly involved in the digestive process. ${ }^{21}$ The other $15 \%$ are small amounts of serum proteins, lysosomal proteins, lactoferrin but essentially a polymorphic glycoprotein without any recognised enzyme activity, the Reg protein, which accounts for $10-14 \%$ of total pancreatic proteins. ${ }^{1422}$ This protein, first identified as a proteolysed product in the autoactivated pancreatic juice, ${ }^{4}$ was found in pancreatic plugs of patients with chronic calcifying pancreatitis ${ }^{6}$ and was shown to be selectively precipitated in concentrated pancreaticobiliary secretions. ${ }^{10}$ All these data favour our earlier hypothesis that the presence of the proteolysed protein in pancreatic precipitates does not reflect the function of the secreted glycoprotein but its suceptibility to proteolysis. ${ }^{23-25}$ In human pancreas Reg was identified only in the exocrine tissue ${ }^{26}$ and secreted as a normal protein of the juice together with the other digestive proteins. However, its biological function in the secretion remains elusive. A potential role for this protein or its precursor in the prevention of pancreatic stone formation has been proposed but recently ruled out. ${ }^{27}{ }^{28}$ It was therefore of interest to investigate the serum level of this protein in patients with $\mathrm{CF}$ in which pancreatic disease is characterised by the presence of plugs within acini and intra- and extra-lobular ducts accompanied by a loose interstitial fibrosis (reviewed by Figarella and Carrère ${ }^{29}$ ).

In the blood of neonates and young infants with $\mathrm{CF}$, in which Crossley et $a l^{\beta 0}$ first noted increased immunoreactive pancreatic cationic trypsin(ogen), we also observed a significant increase in Reg protein, chymotrypsin(ogen), and lipase. The increased serum levels of all these pancreatic proteins in CF neonates is probably due to the presence of a thick pancreatic juice characteristic of the disease, increasing the pressure in the pancreatic duct and leading to increased leakage/reabsorption into the bloodstream. However, our present data show that, whereas secretory digestive enzymes 
disappear from the serum of PI adult patients with CF, Reg protein remains and at an elevated level. In CF patients with PS, in whom the levels of serum lipase and trypsin(ogen) are normal or elevated, the serum Reg level is also significantly higher than in controls and similar to that observed in CF patients with PI. In addition, we found a similar high level of serum Reg protein in patients suffering from CP, as previously observed by Schmiegel et $a^{\beta 1}$ for the homologous pancreatic stone protein.

To be sure that the protein identified in the serum of PI CF patients was similar to that found in PS CF patients, we performed a gel filtration of sera from PS and PI patients. In both cases, the serum Reg protein was eluted in fractions with proteins of molecular mass around $25 \mathrm{kDa}$. A similar elution profile was observed in normal serum with or without an added sample of the purified Reg protein. ${ }^{15}$ These results suggest that the elevated Reg protein concentration observed in CF serum is due to specific and increased synthesis of the pancreatic Reg protein. However, is the serum Reg protein only of pancreatic origin?

The presence of a large amount of Reg protein in the serum of CF patients with PI is indeed surprising and may suggest an extrapancreatic origin which could be related to the previous findings of Hayakawa et $a l^{32}$ and our unpublished data showing the presence of Reg in the serum of pancreatectomised patients. This could explain the lack of correlation between serum levels of Reg and trypsin(ogen) which we found in all sera (controls, CF, and $\mathrm{CP}$ ), contrasting with the excellent correlation observed between lipase and trypsin(ogen) levels in the same sera. ${ }^{33}$ Along the same lines, comparing the ratios between the levels of trypsin(ogen), lipase, and Reg in serum and pancreatic juice, we found that Reg protein concentration was similar to trypsinogen and lipase concentrations in pancreatic juice but four times higher in serum. The possibility of an additional intestinal origin of serum Reg could be evoked, as we previously showed by immunocytochemistry the presence of the protein in the small intestine not only in Paneth cells but also in immature enterocytes. ${ }^{34}$ In addition, we found Reg cDNA at a lower level in jejunum, stomach, and colon. ${ }^{35}$ However, it is interesting to note the lack of correlation between the levels of Reg and of each of the two other proteins in pancreatic juice whereas a good correlation was found between lipase and trypsinogen concentrations. The same difference was observed at the molecular level, as there is no correlation in pancreatic tissue between Reg mRNA and other exocrine protein mRNA, which differs from our previous results showing a correlation between lipase and trypsinogen gene expression. ${ }^{13}$ Therefore, even if serum Reg may be more than an indicator of pancreatic function, the different pancreatic behaviour between this major secretory protein and digestive enzymes remains to be explained.

Is Reg protein a secretory exocrine protein that is different from digestive enzymes and more like a hormonal secretory substance with an endocrine or paracrine function? The presence of elevated levels of Reg in the serum of CF patients is difficult to explain by only an extrapancreatic origin of the protein (because we found it and other pancreatic proteins to be present in very high concentrations in the serum of newborns with $\mathrm{CF}$ ) and suggests that pancreatic Reg is oversynthesised in CF. It is possible that this overexpression is related to the persistence of the inflammatory process in the disease, as it has recently been shown that Reg mRNA expression was strongly induced in a pancreatic acinar cell line AR-42J after treatment with proinflammatory cytokines such as tumour necrosis factor $\alpha$ and interferon $\gamma \cdot{ }^{36}$ Another attractive hypothesis is that the overexpression of pancreatic Reg is due to the relative preservation of the endocrine pancreatic function observed in CF patients. ${ }^{37}$ Histological studies have shown that, in $\mathrm{CF}$, despite large alterations in the exocrine pancreas, the volume density of endocrine tissue is within normal limits and that pancreatic endocrine cell neoformation may be observed. ${ }^{38-40}$ On the other hand, Reg protein has been shown to stimulate islet $\beta$-cell replication in $90 \%$ pancreatectomised rats, ${ }^{41}$ and we recently showed that the reg gene is overexpressed in NOD (non-obese diabetic) mice during active diabetogenesis, in which pancreatic regeneration may occur. ${ }^{42}$ In addition, all studies describing overexpression of pancreatic Reg mRNA dealt with different experimental models of pancreatic regeneration where a $\beta$-cell replicative process was observed (reviewed by Baeza et $a l^{43}$ ). In these models, it appears that the overexpression of the reg gene is rapid but transient, lasting only a few days. It is observed mainly in exocrine tissue during the initial phase of regeneration, suggesting an increased expression after cell dedifferentiation. In contrast with these models, which represent an acute process, CF and, to a lesser extent, CP are chronic processes during which the pancreas is continuously submitted to successive insults possibly followed by attempts at regeneration leading to continuous overexpression of pancreatic Reg mRNA. A careful longitudinal evaluation in CF patients of serum Reg protein concentration in conjunction with other tests of exocrine and endocrine pancreatic function would perhaps help to resolve this issue.

We thank Dr H Okamoto (Tohoku University school of Medicine, Japan) for providing reg cDNA probe and Dr L Christa (INSERM U470, Paris, France) for giving samples of PAP/HIP and its corresponding antibody. The help of Dr C Moriscot for molecular biology experiments is gratefully acknowledged. We are indebted to Dr P Mercier (Centre de Transfusion sanguine, Marseille, France), Dr J P Chazalette (Hopital Renee Sabran, Giens, France), and Dr Y Barbier (Centre Hospitalier Lyon Sud, France) for giving access to control, adult, and newborn CF sera respectively. We acknowledge the help of Professor Berard (Lyon) and Professor Sastre (Marseille) for providing pancreatic juices and pancreatic tissues. This work was supported by a grant from the Association Francaise de Lutte contre la Mucoviscidose (AFLM)

1 Shwachman H, Dooley RR, Guilmette F, et al. Cystic fibrosis of the pancreas with varying degrees of pancreatic insufsis of the pancreas with varying degrees of
ficiency. Am $\mathcal{F}$ Dis Child 1956;92:347-68.

2 Waters DL, Dorney S, Gaskin KJ, et al. Pancreatic function in infants identified as having cystic fibrosis in a neonatal in infants identified as having cystic fibrosis in a neon

3 Durie PR, Forstner GG, Gaskin KJ, et al. Age-related alterations of immunoreactive pancreatic cationic trypsino- 
gen in sera from cystic fibrosis patients with and without pancreatic insufficiency. Pediatr Res 1986;20:209-13.

Guy-Crotte O, Amouric M, Figarella C. Characterization and $\mathrm{N}$-terminal sequence of a degradation product of 14 000 molecular weight isolated from human pancreatic

5 Gross J, Carlson RI, Brauer AW, et al. Isolation, characterization, and distribution of an unusual pancreatic human secretory protein. $\mathcal{F}$ Clin Invest 1985;76:2115-26.

6 Guy O, Robles-Diaz G, Adrich Z, et al. Protein content of precipitates present in pancreatic juice of alcoholic subjects and patients with chronic calcifying pancreatitis. Gastroenterology 1983;84:102-7.

7 De Caro AM, Bonicel JJ, Rouimi P, et al. Complete amino acid sequence of an immunoreactive form of human pancreatic stone protein isolated from pancreatic juice. Eur 7 Biochem 1987;168:201-7.

8 Terazono K, Yamamoto H, Takasawa S, et al. A novel gene activated in regenerating islets. $\mathcal{F}$ Biol Chem 1988;263: activated

9 Watanabe $\mathrm{T}$, Yonemura $\mathrm{H}$, Terazono $\mathrm{K}$, et al. Complete nucleotide sequence of human reg gene and its expression in normal and tumoral tissues. The reg protein, pancreatic stone protein, and pancreatic thread protein are one and
the same product of the gene. F Biol Chem 1990;265:74329.

10 Forstner GG, Vesely SM, Durie PR. Selective precipitation of $14 \mathrm{kDa}$ stone/thread proteins by concentration of pancreaticobiliary secretions: relevance to pancreatic ductal obstruction, pancreatic failure, and CF. $\mathcal{F}$ Pediatr Gastroenterol Nutr 1989;3:313-20.

11 Amouric M, Barthe C, Kopeyan C, et al. Protein X, a proteolysis product of human pancreatic juice. Immunological relationship with trypsinogen 1. Biol Chem Hoppe-Seyler 1987;368:1525-32.

12 Christa L, Felin M, Morali O, et al. The human HIP gene, overexpressed in primary liver cancer encodes for a C-type carbohydrate binding protein with lactose binding activity. FEBS Lett 1994:337:114-18.

13 Moriscot $\mathrm{C}$, Renaud W, Carrère $\mathrm{J}$, et al. Developmental gene expression of trypsinogen and lipase in human fetal expression of trypsinogen and lipase in human

14 Carrère J, Guy-Crotte O, Figarella C. Human pancreatic reg protein: immunoenzymatic assay and molecular form in serum. Clin Chim Acta 1998;273:185-94.

15 Iovanna JL, Ferec C, Sarles J, et al. The pancreatitisassociated protein (PAP). A new candidate for neonatal screening of cystic fibrosis. C R Acad Sci Paris 1994;317: $561-4$.

16 Carrère J, Grataroli R, Marfin J, et al. Non-competitive enzyme immunoassay of human trypsin 1 . F Immunol Methods 1983;60:235-42.

17 Carrère J, Galabert C, Thouvenot JP, et al. Assay of human pancreatic lipase in biological fluids using a noncompetitive enzyme immunoassay. Clin Chim Acta 1986; 161:209-19.

18 Carrère J, Figarella C, Guy-Crotte $\mathrm{O}$, et al. Human pancreatic chymotrypsinogen $\mathrm{A}$ : a non competitive immunoassay, atic chymotrypsinogen A: a non competitive immunoassay, Biophys Acta 1986;883:46-53.

19 Chirgwin JM, Przybyla AE, MacDonald RJ, et al. Isolation of biologically active ribonucleic acid from sources enriched in ribonuclease. Biochemistry 1979;18:5294-9.

20 Renaud W, Merten M, Figarella C. Increased coexpression of CFTR and S100 calcium binding proteins MRP8 and MRP14 mRNAs in cystic fibrosis human tracheal gland cells. Biochem Biophys Res Commun 1994;201:1518-25.

21 Figarella C, Amouric M, Carrère J, et al. Pancreatic proteins in normal state and pancreatic diseases in pancreatic juice and blood. La Ricerca in Clinica e in Laboratorio 1984;14: 349-59.

22 Giorgi D, Bernard JP, Rouquier S, et al. Secretory pancreatic stone protein messenger RNA, nucleotide sequence and expression in chronic calcifying pancreatitis. $\mathcal{F}$ Clin Invest 1989;84:100-6.

23 Figarella C, Amouric M, Guy-Crotte O. Proteolysis of human trypsinogen. 1. Pathogenic implication in chronic pancreatitis. Biochem Biophys Res Commun 1984;118:15461.
24 Figarella C, Amouric M, Guy-Crotte O. Enzyme activation and liberation: intracellular/extracellular events. In: Beger HG, Büchler M, eds. Acute pancreatitis. Berlin, Heidelberg: Springer Verlag 1987:53-60.

25 Figarella C, Basso D, Guy-Crotte O. Lysosomal enzyme activation of digestive enzymes during chronic pancreatitis? In: Beger HG, Büchler M, Ditschuneit H, et al, eds. Chronic pancreatitis. Berlin, Heidelberg: Spinger Verlag, 1990: pancreatiti

26 Satomura Y, Sawabu N, Ohta H, et al.The immunohistochemical evaluation of PSP/reg-protein in normal and diseased human pancreatic tissues. Int $\mathcal{F}$ Pancreatol 1993;13: $59-67$.

27 Bimmler D, Graf R, Scheele GA, et al. Pancreatic stone protein (Lithostathine), a physiologically relevant pancreatic calcium carbonate crystal inhibitor? f Biol Chem 1996;272: 3073-82.

28 De Reggi M, Gharib B, Patard L, et al. Lithostatine, the presumed pancreatic stone inhibitor, does not interact specifically with calcium carbonate crystals. If Biol Chem 1998;273:4967-71.

29 Figarella C, Carrère J. The evolution of pancreatic disease in cystic fibrosis. In: Dodge JA, Brock DJH, Widdicombe JH, eds. Cystic fibrosis current topics. Chichester, New York, Brisbane, Toronto, Singapore: John Wiley \& Sons, 1994;2: 255-75.

30 Crossley JR, Elliott RB, Smith PA. Dried-blood spot screening for cystic fibrosis in the newborn. Lancet 1979;i:472-4.

31 Schmiegel W, Burchert M, Kalthoff $\mathrm{H}$, et al. Immunochemical characterization and quantitative distribution of pancreatic stone protein in sera and pancreatic secretions in pancreatic disorders. Gastroenterology 1990;99:1421-30.

32 Hayakawa T, Kondo T, Shibata T, et al. Serum pancreatic stone protein in pancreatic diseases. Int $f$ Pancreatol 1993;13:97-103.

33 Carrère $\mathrm{C}$, Serre $\mathrm{G}$, Vincent $\mathrm{C}$, et al. Human serum pancreatic lipase and trypsin 1 in aging: enzymatic and immunoenzymatic assays. F Gerontol 1987;42:315-17.

34 Senegas-Balas F, Figarella C, Amouric M, et al. Immunohistochemical demonstration of a pancreatic secretory protein of unknown function in the human duodenum. F Histochem Cytochem 1991;39:915-19.

35 Bartoli C, Baeza N, Figarella C, et al. Expression of peptide $23 /$ pancreatic associated protein and reg genes in human pituitary and adenomas. Comparison with other fetal and adult human tissues. F Clin Endocrinol Metab 1998;83: 4041-6.

36 Dussetti NJ, Mallo GV, Ortiz EM, et al. Induction of lithostathine/reg mRNA expression by serum from rats with acute pancreatitis and cytokines in pancreatic acinar AR-42J cells. Arch Biochem Biophys 1996;330:129-32.

37 Krueger LJ, Lerner A, Katz SM, et al. Cystic fibrosis and diabetes mellitus : interactive or idiopathic? f Pediatr Gastroentrol Nutr 1991;13:209-19.

38 Iannucci A, Mukai K, Johnson D, et al. Endocrine pancreas in cystic fibrosis: an immunohistochemical study. Hum Pathol 1969;15:278-84.

39 Löhr M, Goertchen P, Nizze H, et al. Cystic fibrosis associated islet changes may provide a basis for diabetes. An immunocytochemical and morphometrical study. Virch Arch A Pathol Anat 1989;414:179-85.

40 Craig BG, Johnston CF, Kerr JI, et al. Evidence for pancreatic endocrine cell neoformation in cystic fibrosis. Can $\mathcal{F}$ Physiol Pharmacol 1986;(suppl):399.

41 Watanabe T, Yonemura Y, Yonekura $\mathrm{H}$, et al. Pancreatic beta-cell replication and amelioration of surgical diabetes by Reg protein. Proc Natl Acad Sci USA 1994;91:3589-92.

42 Baeza NJ, Moriscot CI, Renaud WP, et al. Pancreatic regenerating overexpression in the nonobese diabetic mouse during active diabetogenesis. Diabetes 1996;45:65-70.

43 Baeza N, Moriscot C, Figarella C, et al. Reg protein: a potential beta-cell specific growth factor? Diabete Metab 1996;22:229-34. 